УДК 821.163.41.09:398

https://doi.org/10.18485/godisnjak.2020.15.4

Драгана Б. Вукићевић*

Универзитет у Београду

Филолошки факултет
Оригинални научни рад

Примљен: 15. 09. 2020.

Прихваћен: 10. 11. 2020.

\title{
ВЕЛИКА ПРИЧА О КОСОВСКОМ БОЈУ
}

ВЕлиКА ПРичА наратолошки је појам којим се превазилазе жанровске конкретизације и препознаје наративно језгро, исто у различитом. Одлике велике приче препознајемо у многобројним наративима везаним за Косовски бој. О великој причи не пишемо из аспеката идеолошког читања, већ кроз покушаје да препознамо наратолошке специфичности: протежност, трансмедијалност, парадоксалност и оптативност.

Кључне речи: Косово, велика прича, митографизација, трансмедијалност.

Свака књижевност има своје велике приче - а велика прича српске књижевности везана је за Косовски бој. Зачета у првим извештавањима са бојишта, меандрирајући кроз најразличитије жанрове, она се различитим интензитетом приповеда седам векова. Попут феникса, у матици речи, васкрсава некад „случајно”, у разговору кроз узгредне асоцијације, често намерно, кроз уметнички сложене сижејне и тематско-мотивске редескрипције ${ }^{1}$.

*prof.vukicevic.dragana@gmail.com

${ }^{1}$ На пример, у студији Изазови књижевног отпора - рещепиија стварности у савременом српском роману С. Милосављевић Милић пише о „митском хронотопу Косову” који допуњује „конкретизације просторно-временских равни и фактографски аспект њиховог представљања у Карановићевом роману Четири зида и град и Стојановићевом роману $\mathrm{Me-}$ сечева лађа" (2008: 45). 
Појам „велика прича” уводимо да бисмо избегли жанровску конкретизацију дела која се баве Косовским бојем и тиме објединили песме, приче, слике, драме, филмове, позориште. Велика прича је истовремено и минимални садржалац, тачка пресецања различитих наратива и њихова унија - оптимална прича са свим њеним варијететима. Уводимо је као синоним за одомаћене појмове (косовска легенда, косовски мит, косовска предаја, косовско предање) којима су се, у радовима фолклориста, указивањем на заједничко наративно језгро, такође покушале избећи жанровске конкретизације. У нашој интерпретацији појам „велики” не сугерише њен неспорни идеолошки (национални, религиозни, педагошки) значај, о чему је већ писано. У нашем фокусу су њене рецепцијске и репродукцијске специфичности.

Појам велика прича (master narrative) преузет је из наратологије. Жан-Франсоа Лиотар се служи појмовима grand récit и metanarrative за велику причу којом почиње модерно доба а која се зачиње у епохи просветитељства у причама о тријумфу знања, напретку и слободи ${ }^{2}$, јавља се у значењу базичне метафоре, доминирајућег дискурса, културне скрипте преко којих се појединац интегрише у заједницу и обратно (“cultural script or 'dominant discourse' that proliferates in a society" (Hammack, 2009: 51).

У савременим наратолошки енциклопедијама великом причом, међутим, обухваћене су све стратегије приповедања у чијем је гравитационом пољу увек прича-језгро. Било да се новостворене приче јављају као њене варијације, по принципу синонимије (сличне приче) или контраста (супротстављени наративи), и у једном и у другом случају - приче се обликују у орбити приче-језгра (core fabula). (У Уводу у теорију прозе Х. П. Абот пише о причама које су, без обзира на интерпретативну отвореност и варијантност, с обзиром на различитост времена када се изнова јављају, задржале своју препознатљиву основу (Абот 2009: 290).)

У фолклористици, с обзиром на висок степен формулативности и на естетику истоветности, поновљене приче врло рано су се нашле у фокусу истраживача (понављање је у фолклору conditio sine qua non). Али, пре него што покушамо да објаснимо зашто смо једној из репертоара поновљених прича дали придев велика, задржаћемо се на наративном минимуму - оном који чини косовску причу препознатљивом.

${ }^{2} \mathrm{O}$ Лиотаровој критици поверења у „велике нарације еманципације универзалног субјекта", а у контексту српске савремене прозе в. рад. С. Милосављевић Милић: Интерпретацијски кодови семантичке опозииије наше и страно у књижевности (2006: 11).

${ }^{3}$ B. студију индикативног наслова: Putting the Social into Personal Identity: The Master Narrative as Root Metaphor for Psychological and Developmental Science, https://www.karger.com/ Article/FullText/446054, прегл. 15. 12. 2020. 


\section{Минимална велика прича}

Битка која се одиграла 15/28. јуна 1389. била је пресудни историјски догађај, иницијална каписла за стварање циклуса, међаш нове класификације песама унутар жанра (прекосовски, косовски, покосовски циклус). О значају битке Вук Стефановић Караџић је писао: „Ја мислим, да су Србљи и прије Косова имали и јуначки пјесама од старине, но будући да је она промјена тако силно ударила у народ, да су готово све заборавили, што је било донде, па само оданде почели поново приповиједати и пјевати" (Караџић, 1975: 569) 4 . Забележене у устаничким годинама, ове песме су, уз лазарице, и у тематском прожимању са српском средњовековном књижевношћу (списима литургијског карактера о кнезу Лазару, на пример), образовале „причу коју изнова препричавамо у безброј различитих облика" ${ }^{5}$, кОсовску велику ПРИчу (masterplot). ${ }^{6}$

„Косовским пјеснама” Караџић је назвао „песничка остварења слепице из Гргуреваца добијена, како је сам написао, у рачуну од пјесама, током 1817. од Лукијана Мушицког. Песме је објавио у другој књизи лајпцишког издања, 1823. под насловом: Обретеније главе кнеза Лазара, Пропаст изарства српскога и Косовка ђевојка" (Костић 1987: 76). Овим песмама велика косовска прича није почела. Караџићеве косовске песме не издвајамо као прве, нити у њима препознајемо „ген сижеа”. Многи сижејни рукавци велике приче (везани за Лазареве кћери и њихову свађу, односе између пашенога и сл.) нису из њих изведени. Ипак, оно што их издваја од осталих, везано је за њихову рецепцијску доминацију и популарност у 19. веку. Оне су значајне јер су постале поредбени стожер, нека врста оријентирне тачке у односу на коју се самеравало одступање и различитост. Изабране су захваљујући антологијској вредности која им је у романтизму придата (естетска валоризација) и културнополитичком значењу препознатом у актуелној романтичарској националној аутоидентификацији (идеолошка валоризација).

У студији Косовска битка у усменој поезији о сличности различитих књижевних жанрова који су тематизовали Косовску битку Соња Петровић

${ }^{4}$ В. Караџић, Српске народне пјесме, 1 , предговор лајпцишком издању 1824 , Сабрана дела Вука Караџића 4, Београд 1975: 569.

${ }^{5}$ У Уводу у теорију прозе Х. П. Абот велику причу дефинише као „причу коју изнова препричавамо у безброј различитих облика" (Абот 2009: 87).

${ }^{6} \mathrm{O}$ појму велика прича, који користимо да бисмо избегли жанровско сужавање и ограничавање на епску песму, легенду, предање и друге облике у којима се велика прича јавља, писали смо у раду Косово и реторика антијунака. Овај рад је излаган на скупу фолклориста посвећеном Косову и одржаном у Крушевцу 2019. Рад је објављен у зборнику Савремена српска фолклористика 6. 
пише: „Стилизација ликова и ситуација, устаљене фразе и изрази, препознатљиви атрибути јунака чине костур, потенцијалну сижејну констукцију, а он је у великој мери заједнички у приказима исте теме у разна времена и на различитим просторима без обзира на књижевни жанр" (Петровић 2001: 11). Поднасловима, полазећи од ширег корпуса текстова о Косовском боју, Петровићева маркира теме које сматрамо кључним тачкама пресека различитих наративизација битке: предсказање („пошљедње време”, снови, пропаст царства и смак света); долазак Турака; Муратово писмо Лазару; Лазарево опредељење за царство небеско; кнежева клетва; свађа Лазаревих кћери и сукоб зетова; издајник и оклеветани јунак; причешћивање војске и веридба јунака уочи боја; одвраћање од боја; ухођење војске; кнежева вечера; јунак, судбина жена̂ после боја; посвећење кнеза Лазара (Петровић: 2001).

Управо захваљујући препознатљивим тачкама укрштања, велика косовска прича се могла покренути и кроз један фрагмент (тему, име јунака, стих). Могла се ширити, привучена другим „фрагментима” или скупљати чувајући препознатљив „ген”. Процес ширења могао је бити у знаку центрипеталних сила образованих око језгра или тангентног одступања од традицијом формиране „наративне орбите” (таква су пародијска исклизнућа приче). То је заправо значило да је велика прича, „прича која узима предујам"7, јер се њоме, поред директне, увек активирала индиректна комуникација, тј. њен реципијент се истовремено препуштао ономе већ схваћеном, испричаном и оном што се кроз њу сада приповеда као исто, слично или опозитно. Та „прича предујам”, која би покренута контекстом варирала кроз најразличитије наративе, подразумевала је минималну наративну обавештеност - догодила се Косовска битка, у њој је Милош убио цара Мурата, а Вук Бранковић био издајица.

Зашто је ова прича имала снагу инспирацијског и интерпретативног замајца? Зашто је управо она постала херменеутичка „шифра” у новим естетизацијама и идеологизацијама стварности?

Јошт не знате што сте урадили док чујете од вјешта гуслара (Лажни ц̧ар Шћепан Мали, П. П. Његош)

Неретко се великој причи придаје снага алегоријског кључа, ексклузивне приче, херменеутичког оруђа у рукама одабраних - оних који припадају упућеној привилегованој заједници њених интерпретатора (они

${ }^{7}$ Појам „прича с предујмом” преузели смо из студије Н. Лумана: Љубав као страст, прилог кодирању интимности, Сремски Карловци - Нови Сад: Издавачка књижарница Зорана Стојановића, 2010, стр. 35. 
су истовремено и њени произвођачи, они који обнављају, максимализују почетну „малу причу”, али и њени вантекстовни ,јунаци” интерпретирани њоме). Тиме се границе између праве и наративне публике непрестано померају и прича се скупља или шири, фигуративно, пулсира попут срчаног мишића.

Издвојили смо неколико услова њене виталности:

А) протежност,

Б) трансмедијалност,

В) парадоксалност,

Г) оптативност.

Захваљујући њима, семантичка апсорпцијска моћ велике приче - могућност да постане прича означитељ за најразличитија искуства и препокрије најразличитије стварности - непрестано се обнављала.

\section{А) Протежност}

Под протежношћу приче подразумевамо способност њеног ширења и скупљања; на пример, скупљање приче можемо пратити у биографијама јунака које стају у једну реч, у именовање некога Обилићем или Вуком. Будући да „велику причу карактерише појава типова, односно карактера чији је психолошки профил и мотивација саставни и уобичајени елемент велике приче" (Абот 2009: 290), у косовској великој причи, Милош и Вук примарно се издвајају у групу „типова” који се „могу употребити као моћна реторичка средства" (Абот 2009: 290). Њима се придружују Мурат, кнез Лазар, Косовка Девојка. Они су истовремено јунаци омеђени конкретним наративним световима и потенцијално генеришуће фигуре са јаким реторичким потенцијалом: јављају се реторски удвојени, у поређењима, антитезама, метафорама, симболима; у актуализованим, и виртуелним наративима: у хипотетичким фокализацијама, посибилним нарацијама (шта би било да су живи), у негацијама (ламентима што нису живи) или поређењима (ланац јунака повезан поредбеном копулом „као”).

Синонимски низ може обухватити најразличитије јунаке: на пример, у беседама Гаврила Стефановића Венцловића библијски садржаји постају пријемчивији пастви уколико им се предоче преко познатих (усмених) прича. У синонимском низу „Милош Обилић” тако се нашао библијски јунак Самсон. У Вуковим портретима устаника, синонимском низу „Милош Обилић” придружује се војвода и јунак из Првог српског 
устанка, Милош Стоићевић. ${ }^{8}$ Каква је сличност између Самсона, Обилића и Милоша Стоићевића? Из биографије јунака је довољно активирати један елемент (то може бити снага и херојство, оклеветаност, цароубиство) да би се покренуо асоцијативни низ и успоставила синонимија (у изабраним примерима - снага и херојство). Притисак имена је толико јак да идентификација може бити делимична и да прича о новом Обилићу нема више никаквих додирних тачака са кругом прича о косовском боју. Ипак, самим поменом јунака и ови наративи пролазе кроз орбиту велике приче.

C друге стране, у самом језгру приче, непрестано се умножавају „исти” јунаци. Прича се кроз разне варијанте шири, допуњује „истим” актерима, само у другим наративним световима. Различити Обилићи стварају алтернативне биографије истог јунака - име се преноси попут гена: црте се повезују, спајају, стварају нове. Налазимо се у Долежеловом трансветовном наративном универзуму испуњеном путујућим јединакама (опет исти јунак, али мало/много другачији). Без обзира на новине, на другачије генетичке модулације, серије нових трансветовних јунака увек имају јединствен идентитетски белег. (На пример, о генетичким модулацијама Сарајлијиног и Стеријиног Милоша Обилића детаљно је писала Снежана Самарџија, препознајући сфере укрштања различитих Обилића у једном лику: она пише о сложеној фигури Обилића, чији „генетички” материјал се црпи из најразличитијих текстова - бугарштица, Рајића, Вука итд.). ${ }^{9}$ Као „најјачи” ген по правилу се препознаје „вуковски” и њиме се

${ }^{8}$ У биографији Милоша Стоићевића, Вук Стефановић Караџић непосредно истиче ово изједначавање јунака са Милошем Обилићем. Он пише: „Млого је његовом јунаштву помагало што је све помишљао на Милоша Обилића, који је, као што се пева и приповеда, такође био из Поцерине, а кажу да га је и Црни Ђорђије тога опоменуо кад га је завојводио" (Караџић 1964: 127-128). О преплитању реалија (документарног) са епским у биографијама јунака в. Пешикан Љуштановић, „Пушка опутом свезана”, у: Пищем ти причу, 2020: 42.

'У минуциозним анализама драме 'Трагедија Обилић' Симе Милутиновића Сарајлије, „прве драме о косовским јунацима и догађајима који ће постати важна инспирација многим књижевницима 19. и 20. века", Снежана Самарџија прецизно реконструише тачке пресека, потврђујући флуидност велике приче: „Тако његов Обилић представља спој свих токова стилизације Првог косовског боја - обједињује дух Вукових записа са традицијом познатом састављачу Троношког родослова, повезује елементе 'приче' излагане на страницама историјаิ, од Орбина до Рајића, са стиховима и варијантама из разних рукописних и штампаних песмарица. Ти мотиви, опевани и међу бугарштицама, представљају Милутиновићево полазиште за битне епизоде, заплете и ликове Трагедије. Директан удео сигурно је имао и Качићев Разговор, којим се Сима детаљно бавио при превођењу” (Самарџија 2018: 138). Другачији су алтернитети Стеријиног Милоша Обилића: „Треба напоменути да се, првенствено на нивоу сижеа, његово дело подудара са виђењима косовског боја код Мавра Орбина (Краљевство Словена, Пезара, 1601), са изузетно популарном Качићевом песмарицом (Разговор угодни народа словинскога, Венеција 1756), са рукописним верзијама Приче о боју косовком, Историјом Јована Рајића, али и са спевом земунског књижара Гаврила Ковачевића, објевљеним 1805” (Самарџија 2018: 171). 
све самерава. Снежана Самарџија, на пример, бележи линије одступања: „За разлику од Вуковог епског распореда, који истиче улогу и ореол кнеза Лазара, бугарштице у први план постављају Милоша, а мотивацију сукоба померају ка породичним и ритерским релацијама" (2018: 170). Нови Обилићи (Сарајлијин и Стеријин) сагледавају се упркос „терету” наслеђа, више као нови него као поновљени „стари” (вуковски) јунаци.

Истраживања „истог” у различитом, и различитог у истом (препознавање „особних лазарица”, „особних милошица”) постаје занимљива игра добро обавештеног читаоца повлашћеног знања који може да прати приближавања и удаљавања „наратива”, што додатно потврђује виталност велике приче и њену протежност, способност да се шири у сваком сегменту, стварајући гроздасте наративе. Бујање гроздова, притом, не прети опстанку велике приче, напротив. „Особне лазарице” и „особне милошице" ${ }^{10}$ неретко су канали преко којих се актуализује Косовски бој и симболички повезује са савременим приликама из ауторовог живота. У причу-језгро инфилтрира се, на пример, биографски или политички наратив, а сам аутор постаје место укрштања животних искустава са најразличитијим праксама читања у које улази и „велика прича” (О симбиотичком писцу-читаоцу Барт пише: „Ја које прилази тексту већ је само по себи плуралност других текстова, кодова који су бескрајни или, тачније говорећи, изгубљени (чије је порекло изгубљено) ${ }^{11}$ - Барт 1970: 10). Тако, парадоксално, оно што је „девијантно” (индивидуално) заправо постаје потенцијално нови регенерацијски заметак велике приче која се наставља приповедати. Нови наративи се гроздасто уланчавају, а велика прича не бива угрожена њиховом специфичношћу. Навешћемо три примера:

У Његошевом Горском вијениу у којем се дванаест пута помиње Обилић, у коме „Обилића певају, Обилићем се куну, Обилићем живе” (в. Велимировић 1994: 189) митеме о издајницима и херојима су активиране, а природна-космичка и религијска неминовност победе ових других (хероја) „пренета” у актуализован свет, на историјско време истраге потурица ${ }^{12}$.

${ }^{10}$ Снежана Самарџија, на пример, пише о Сарајлијиној „особеној Лазарици” (2018: 138), о Стерији, који пише ,једну својеврсну драмску „Лазарицу” или „Милошицу” (2018: 178).

${ }^{11}$ Архивско трагање за „изгубљеним” посебан је изазов у реконструкцији наратива о Обилићу у ауторизованим текстовима који су мета фолклористичких анализа.

${ }^{12}$ У студији „Предање у Горском вијениу” Љиљана Пешикан Љуштановић пише о дубљој идејној повезаности драмског спева и епског предања заснованог на „кружној космогонији” и „нужности периодичног обнављања света угроженог људским безакоњем” (2009: 38) У основици спева она препознаје „историзована есхатолошка предања народне традиције” (2009: 38). 
У Милутиновићевом читању традиције, „судбина епског јунака прераста лично име и индивидуалну коб, а постаје симбол трајања сваког појединца и народа" (Самарџија 2018: 164).

Придружујући се читаоцима (Јован Ристић, Драгиша Живковић) који сматрају да „трагичка Стеријина визија српске историје не одговара интениијама вуковске глорификаиије српске историје" (Живковић 1970: 53, подв. Д. Вукићевић), Снежана Самарџија ипак закључује: „Стерија је и самој традицији отварао путеве у новим и измењеним условима трајања усмене уметности речи" (Самарџија 2018: 195). ${ }^{13}$

Наратив се може ширити у свакој секвенци (игноришући) остатак приче. На пример, на пољу визуелних наратива, активирање различитих секвенци велике приче можемо сагледати упоређивањем различитих ликовних представа боја: Адама Стефановића, Уроша Предића, Паје Јовановића, Петра Лубарде, Оље Ивањицки, Петра Радичевића. ${ }^{14}$ На платну Адама Стефановића у фокусу је Кнежева вечера, код Предића завршница битке, код Лубарде - сам бој. Убацивање визуелних наратива у причу води нас ка другом „гаранту” виталности велике приче - трансмедијалности.

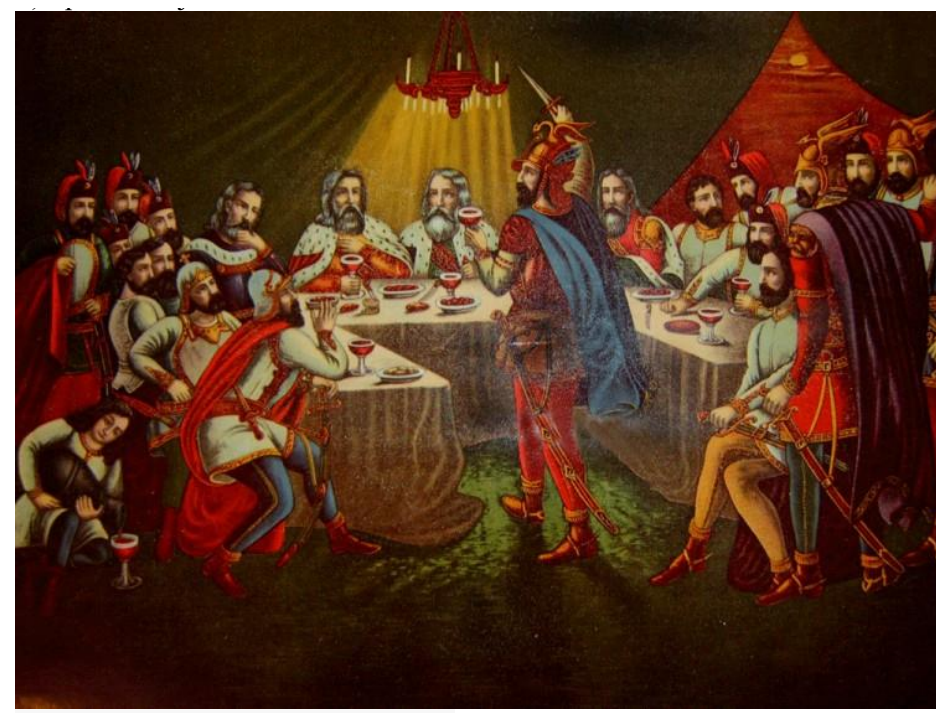

Адам Стефановић, Кнежева вечера

${ }^{13}$ О односима епско - историјско - трагично в. студију „Може ли Историја бити трагички јунак”, у: Зорица Несторовић, Богови, иареви и људи: Трагички јунак у српској драми ХІХ века, Београд, Чигоја штампа, 2007, стр. 97-136.

${ }^{14} \mathrm{~B}$. информативне чланке са преузетим илустрацијама: http://www.serbum.rs/kosovskiboj-u-srpskom-slikarstvu/; https://www.glassrpske.com/cir/kultura/kultura_vijesti/kosovski-boj-veliki-motiv-srpskog-slikarstva/287273. 


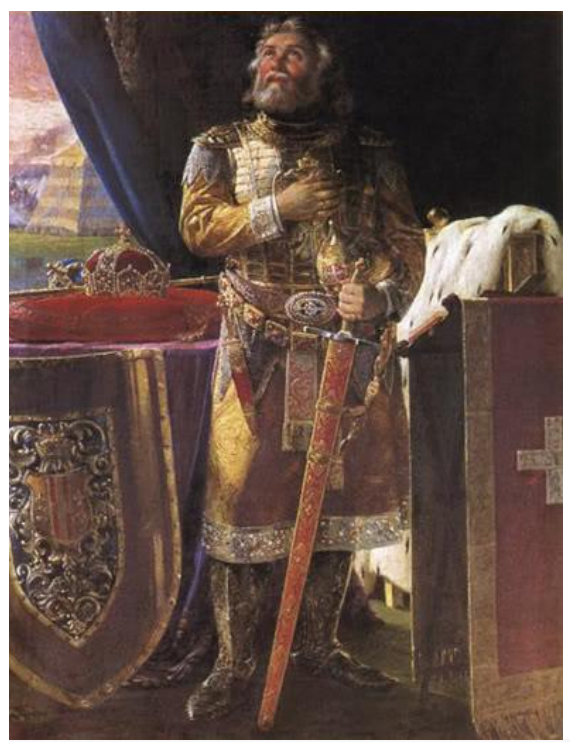

Урош Предић, Кнез Лазар се одриче земальког ичарства

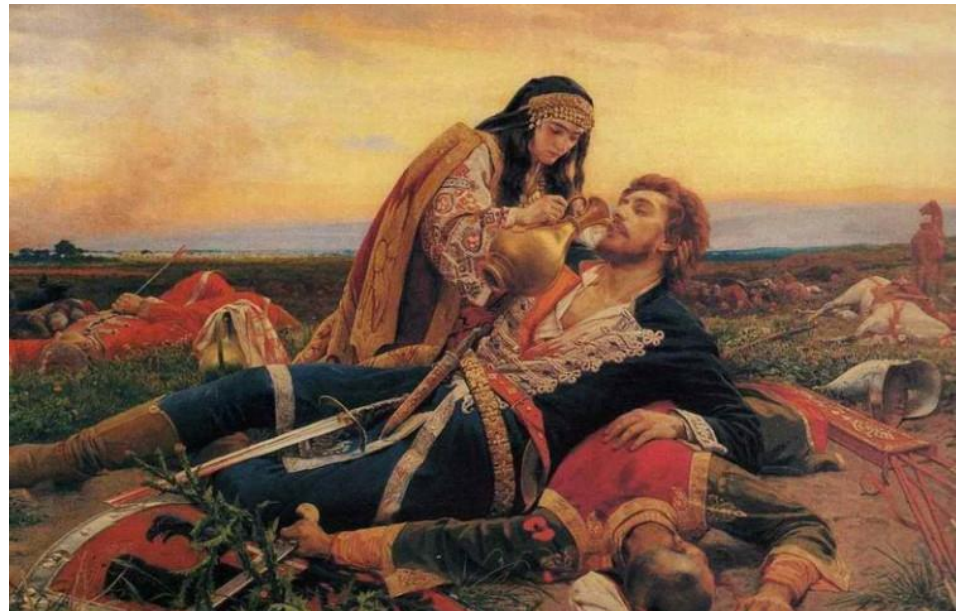

Урош Предић, Косовка Девојка 


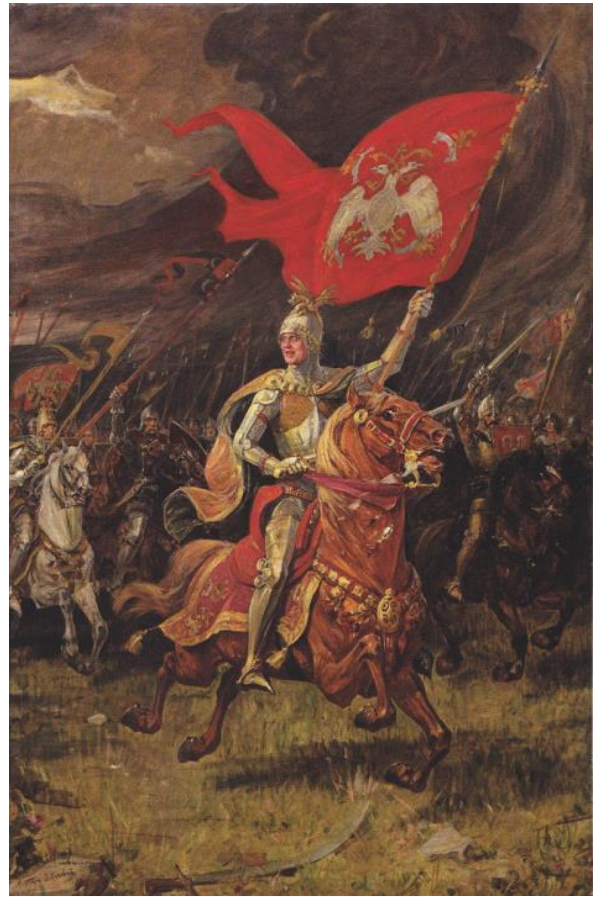

Паја Јовановић, Бошко Југовић

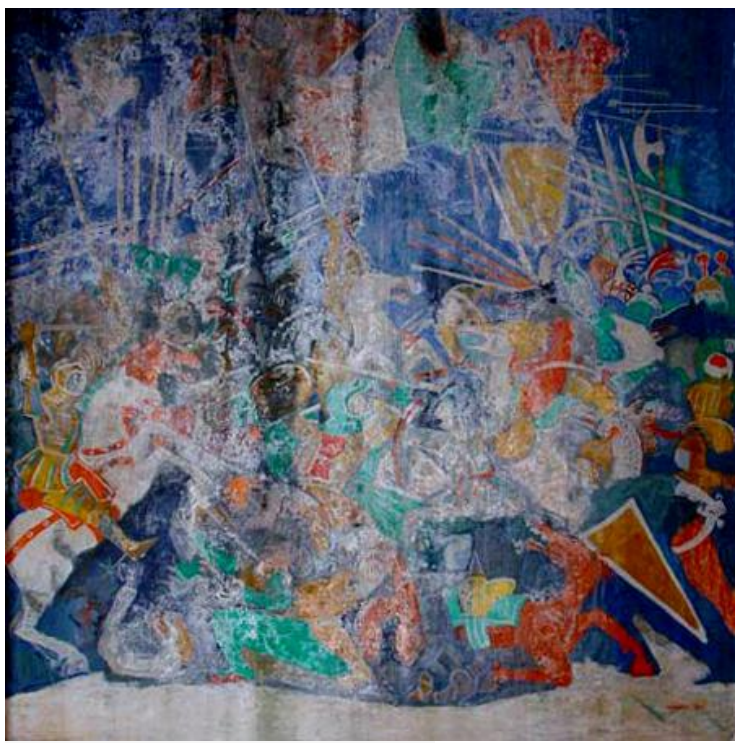

Петар Лубарда, Косовски бој 


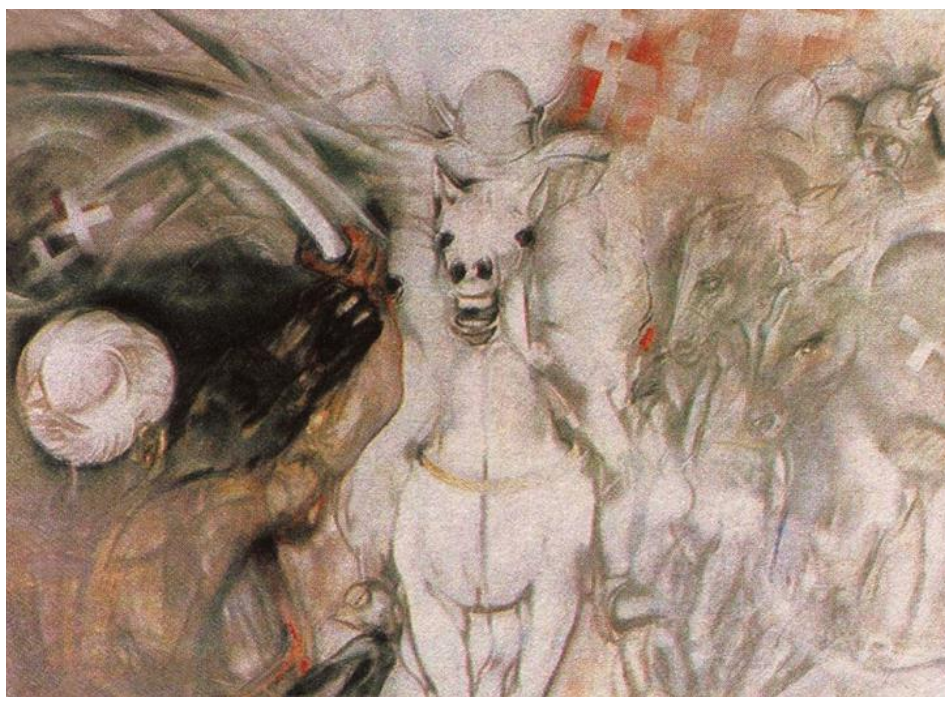

Оља Ивањицки, Бој на Косову

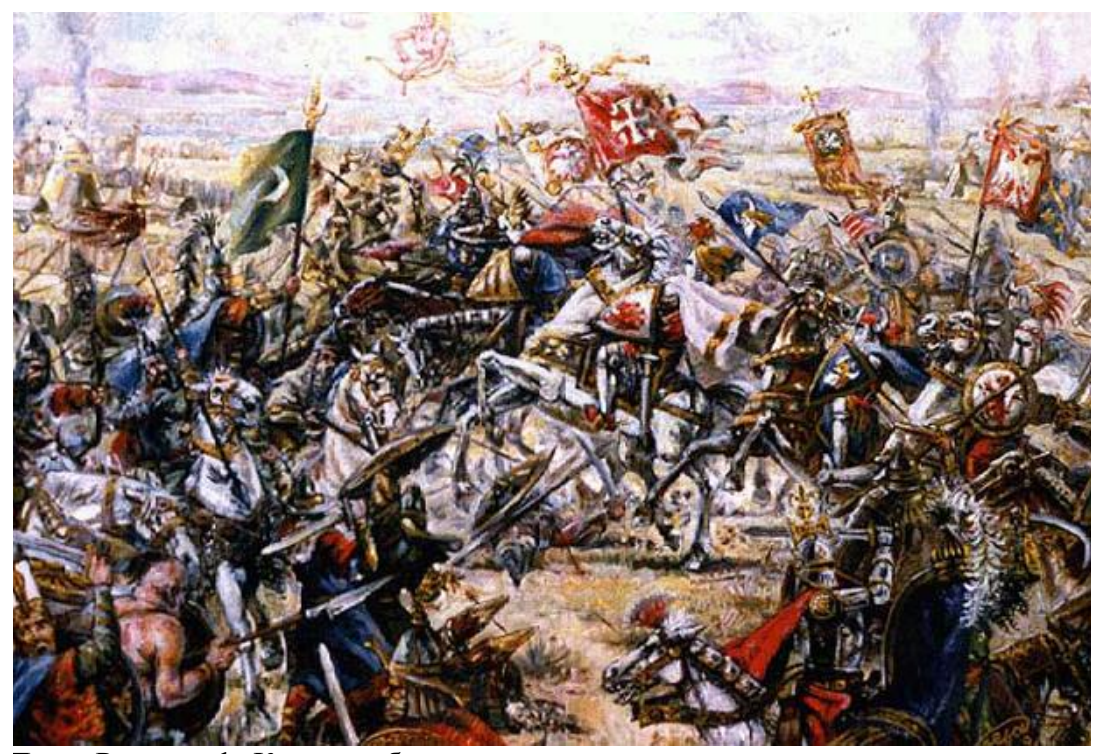

Петар Радичевић, Косовска битка 
„Може ли ко поштовати једну кућу без таквих слика?”

Продуктивност велике приче и њена трансмедијална флуидност ${ }^{16}$ манифестовала се њеном заступљеношћу у књижевности, у позоришној, ликовној, примењеној уметности. Нарочито су јубилеји били повод за праву експлозију трансмедијалних наратива - хиперпродукцију велике приче. На пример, поводом обележавања значајног јубилеја Шест стотина година од Косовског боја, Љубомир Рељић, на основу материјала из музеја у Србији, прати како се косовска легенда испољила у народном стваралаштву, у радовима самоуких народних уметника (цртежима, сликама, предметима за свакодневу употребу). Косовска велика прича се утискује у вез, у обредни хлеб: „Према народном предању, везиље су везле причу о 'круни' цара Лазара, о 'топузима' српских јунака, о 'путирима' из којих су пили вино. Стилизоване црвене божуре на женским зубунима опточиле су црним нитима. Из исте традиције, и домаћица је у култне и обредне хлебове утискивала не само хришћански поскурник већ и шаралицу у чијем се отиску тек наслућује, а понекад и јасно разазнаје мотив 'двоглави орао', симбол српске државе Немањића и Лазаревића" (Рељић, б. г. 6).

После сеоских средина, „велика прича” о ,јунацима и коњима њиховим" (В. Караџић), о страдањима, пошљедњим временима и царству небеском, „била је у моди” и у градским срединама. Тако је, на пример, крајем 19. века било уобичајено продавање луксузно опремљених великих слика са историјским мотивима намењених украшавању грађанских салона. У студији Изглед грађанских ентеријера у Новом Саду крајем 19. и почетком 20. века Љиљана Лазић запажа популарност историјских мотива оцртаваних на предметима за свакодневну употребу (чашама, тањирима, бокалима итд.): „Биле су то доста наивно илустроване култне сцене из националне историје (Срби око гуслара, Косовка Девојка, и др.),

${ }^{15}$ У студији Љиљане Лазић Изглед грађанских ентеријера у Новом Саду крајем 19. и почетком 20. века читамо да су се: ,слике Паје Јовановића (Таковски устанак, Издајица, Мачевање, Борба петлова), Уроша Предића (Косовка Девојка, Весела браћа, Хериеговачки бегунци), Ђорђа Крстића (Свети Сава благосиља Српчад) и Јарослава Чермака (Рањени Црногораи) продавале као луксузно опремљене велике слике, намењене украшавању грађанских салона. Позиве српској популацији да купују олеографије редовно је упућивао и Анастас Боцарић, још један уметник чија су дела више пута графички умножавана: 'Наше су куће без њихових слика хладне и одвратне, као медвеђе пећине и циганске черге. Украсимо наше домове једино српским сликама, оне су књига, која се никад не затвара и коју чита сваки - учени и неуки! Може ли ко поштовати једну кућу без таквих слика?"” (Лазић 1998: 35).

${ }^{16}$ О природи наратива неовисној од медијума („medium independent nature of narrative”) опширније су писали Клод Бремон и Ролан Барт. Клод Бромон је давне 1964. сугерисао да се приче могу премештати из медијума у медијум, а да очувају основну препознатљивост. В. Рајан (Ryan): Media and Narrative, 2008: 289. 
ликови владара, јунака, светитеља и песника, често праћени натписима, стиховима и порукама патриотског садржаја" (Лазић 1998: 35). Ауторка открива да садржаји нису били само естетски пријемчиви: „Олеографије са историјским садржајима (Југ Богдан, Кнежева вечера, Косовски бој, Косовка Девојка, Спаљивање моштију Св. Саве и друге) имале су функцију јачања националне свести, али и развијања уметничког укуса који није одступао од академског сликарства друге половине 19. века" (Лазић 1998: 35).

Ови кратки цитати за нас су значајни јер указују на разноврсност „канала” који су преносили велику причу: од хлеба и утиснутих шара, чаша, до уметничких дела. У 19. веку медиј значајан за ревалоризацију косовске приче било је позориште. ${ }^{17}$ Извођена у позоришту, псеудоисторијска драма је пленила естетиком препознавања - задовољством гледања онога што се „само читало или слушало”. Том аутоматизованом рецепцијом може се објаснити склоност публике, о којој пише Марта Фрајнд, да „превиди једностраност психологије коју су испољавали (драмски) јунаци" (Фрајнд 1987: 12). ${ }^{18}$

У савремено доба трансмисиони канали (телевизија, радио, интернет) у техничком смислу омогућавају већу експанзивну моћ и масовнијег ,конзумента" приче. ${ }^{19}$ Просторно-временску екстензију приче кроз различите медије потврђује и популарност филма Бој на Косову из 1989. године, у режији Здравка Шотре. ${ }^{20}$ Семантичка овисност велике приче од медија и тумачење медија не само као канала већ и жанра (в. Ryan: Media and genres, Media and narrative, 2008: 288-290), теме су, међутим, неког другог рада.

${ }^{17}$ Посебну пажњу посветићемо позоришту и жанровима (попут псеудоисторијске драме) који су били драмске „редескрипције”/"рекреације” епског наратива, као и мелодрамски интонираној прози која је активирала драмско баладични потенцијал епских текстова. Они су тема другог рада посвећеног великој косовској причи.

${ }^{18}$ Епизација драмског исказа није, међутим, могла проћи без последица по аутономију самог жанра. Криза драмског жанра се испољавала у суштинској некомпатибилности радње која се дешава и радње која се приповеда. Од кључа који „обкључава” (С. М. Сарајлија), епски претекст је постао оков који стеже и гуши клицу, семе драмског. О овој „побуни жанра” више у раду посвећеном механизмима жанровске виталности велике косовске приче.

${ }^{19}$ У наратолошким проучавањима разликују се трансмисиони канали (телевизија, радио, интернет, грамофон, телефон, али и књига, новине) од семиотичких (језик, звук, слика, бронза, људско тело, камен) преко којих се „шири”, „посредује” прича (в. Ryan: Media and genres, Media and narrative, 2008: 288-290).

${ }^{20}$ Репертоарска политика емитовања овог филма у кључним тренуцима (нпр. на вест о смрти значајних црквених велодостојника) сведочи и о друштвеној репрезентативности и јаким идеолошким импликацијама наратива. 


\section{В) Парадоксалност}

Поред помунутих карактеристика, протежности и трансмедијалности $^{21}$, као кључно обележје великих прича издвајамо парадоксалност. Само висок степен парадокса омогућава обновљивост приче и превладавање искључивости и ограничења једне приповедне опције. У студији Љубав као страст, прилог кодирању интимности Никлас Луман запажа да се парадоксалност показује „као техника са великим системом систематизовања; а систематизовање је облик у коме се може остварити стабилност и за невероватне захтеве понашања" (2010: 87). Приче о настанку, смаку, васкрснућу спадају у ред таквих прича. У њих убрајамо и косовску велику причу која је, захваљујући парадоксу, могла апсорбовати најразличитије манифестације аморфне стварности; њоме су се могле препокрити искључиве реалности - приповедати о губитнику као о победнику, „издајнику” заправо хероју, умрлом као о васкрслом, жртвованом као победнику, победнику као побеђеном итд. Могла је у сваком моменту да се заврши и да започне јер су се и почеци и завршеци сустицали у цикличном наративу о смрти, обнови и васкрсењу. Као и све велике приче, захваљујући својој моћи да апсорбује искључивости, косовска велика прича постала је начин редескрипције и реинтерпретације актуелне динамичне и метаморфичне стварности („Што је велика прича више укорењена у некој култури, то је њен утицај на свакодневни живот снажнији”, Абот 2009: 87).

Велике приче стварају велике (многољудне) „интерпретативне заједнице" које (perpetuum mobile) њих непрестано ревитализују. ${ }^{22}$ Интерпретативну заједницу чине они који знају „предујам” причу и који је лако могу препознати (оживети). Велика прича, дакле, постоји унутар интерсубјективне комуникационе мреже па се не може уништити кривотворењем или драстичније, заборавом појединца. Она је „отпорна” на ауторске интерпретације јер их, једанпут покренута, или игнорише или подређује. Она снагом парадокса апсорбује свако неслагање, складишти опречне могућности, предвиђа отпор неинтерпретираног догађајног и процесуалног, баца у заборав чињенице, истину, стварност, све оно што је инцидентно у односу на структуру и што се не може подвести под њен

${ }^{21}$ Попут приче о старости кокошке или јајета, и ми остављамо отвореним питање да ли су приче велике зато што су трансмедијалне или су трансмедијалне зато што су велике? У сваком случају трансмедијалност је пратеће обележје великих прича.

${ }^{22} \mathrm{O}$ интерпретативној заједници и различитим интерпретантима (сходно тријадичној подели аутор: дело: читалац) на примеру романа Месечева лађа Радосава Стојановића, в. рад С. Милосављевић Милић, Интерпретацијски кодови семантичке опозиције наше и страно у къижевности 2006: 11. 
наративни жрвањ. Између косовске велике приче и докумената очевидаца и учесника најразличитијих сукоба и ратова (Први и Други српски устанак, Српско-турски ратови 1876-78, светски ратови, сукоби 1999. год.) тешко се може успоставити знак једнакости. Ипак, једном „повезани”, у радијацијском пољу косовске велике приче, догађаји постају семантички „озрачени”; нови Обилићи се изнова генеришу, препознају, сходно времену, у устанцима, у Великом рату, у социјалистичкој револуцији итд. ${ }^{23}$ Пролазећи кроз чвориште сложене фигуре (протежност и парадоксалност), косовски јунаци су се непрестано „одржавали” живим. Управо је историјски разноврсна публика омогућавала обновљивост велике приче, различитост њених значења у различитим временима (Идеални читалац који би требало да изврши ,,укупну потрошњу текста” (,total consumption of the text”, Изер 1978: 29) учинио би причу мртвом, необновљивом). Преко Шехерезадиног синдрома и рецепцијског парадокса - велика прича је истовремено била произведена, али је и сама производила своје „произвођаче" - како оне који су је причали, тако и оне који су је слушали или бивали препознати у њој.

Фрагментизовање приче на секвенце које су се могле склапати и припајати различитим сижеима, попут Рубикове коцке (али са отворено проширивим могућностима комбинација) омогућавало је уланчавање у исти низ најразличитијих ратних наратива. На пример, инспирисан Јакшићевим приповеткама о српско-турском рату, ово уланчавање примећује и Јован Скерлић: „Ратови од 1876-1878 за њих (Јакшићеве савременике, прим. Д. В.) значили су освету Косова и васкрс српске славе, и Змај Јован Јовановић је на корицама своје Илустроване ратне кронике ставио два датума: 1389-1877” (Скерлић 1956: 378). ${ }^{24}$ Овај процес „изједначавања”

${ }^{23}$ У студији Косовска легенда у народном стваралаштву Љубомир Рељић наводи неколике примере ревитализације обилићког херојства у различитим временима и с различитим циљевима. Неке препознајемо кроз политичку манипулацију: „Те особине косовских јунака користиће и страни државници кад им то буде одговарало. Тако је Јосиф Други, позивајући 1789. Србе у рат против Турака, у свом прогласу захтевао од српских бораца да буду јунаци као Милош Обилић”. Други је пример колективне визије: „Сведочанства о томе како су у рату 1912. српски сељаци доживели визију да у току битке виде пред собом Милоша Обилића, ушла су и у страну митолошку литературу”. Следећи пример Рељић везује за албанску голготу и „косовску мисао да је изгубљена отаџбина још увек отаџбина” (Рељић, б. г. 69).

${ }^{24}$ „Обезбеђивање вероватноће за прихватање невероватних захтевања”, што је предуослов парадоксалних прича које имају јаку „апсорпцијску моћ” (Луман 2010: 87), у случају косовске велике приче, већ је потврђено и препознато у радовима фолклориста (индикативни су наслови: Пад Босанског краљевства и косовска традищија (Дејан Илић) или Косовски бој у устаничкој традицији (Бранко Златковић), који управо потврђују „проточност” косовске приче кроз најразличитије историјске наративе. У раду Косовски образаи у јужнословенској и руској усменој поезији Данијела Петковић прати како се у епици усменопоетски уобличавају битка на 
времена понављаће се све до ратова који су 90-их година прошлог века захватили подручје бивше Југославије (тако је 1389. била и 1999. када је Србија била бомбардована) ${ }^{25}$. У широком временском луку косовска велика прича се при сваком великом сукобу изнова активирала. Истовремено је била и интерпретативна матрица за тумачење актуелних догађаја, и једна врста филтера најразличитијих идеологија (од оних које су славиле српски национ до оних које су величале идеју југословенства). ${ }^{26}$

Ипак, уланчани у једну надтекстуалну целину, ратни наративи су показивали извесну правилност у активирању велике косовске приче: офанзивне приче активирале се обилићки наратив, а дефанзивне - Лазарев избор. Тако се, као кроз Сцилу и Харибду, кроз полове победе и пораза, кроз разноврсје историјски или псеудоисторијски редукованих конкретизованих причања, увек изнова помаљала обновљена велика прича.

\section{Г) Оптативност}

Кроз еп, преко драме, прошлост Срба је постајала селективно херојскија него што је била. Парадоксално, велика косовска прича (иако прича о прошлости) увек је имала футуристичку димензију; реферирање

Царевом Лазу, Куликовска битка, Камска битка; у раду Пад босанског краљевства и косовска традиција Дејан Илић повезује пад краљевства са крајем земаљског царства и судбинском предодређеношћу пада, док Бранко Златковић у раду Косовски бој у устаничкој традииији прати како се у устаничкој традицији формира „култ ратника Милоша Обилића и исказује се кроз предања о топонимима који се везују за њега, као и кроз анегдотска казивања о његовом устаничком двојнику војводи Милошу Стојићевићу Поцерцу”. Промишљајући „Косовски бој у устаничкој традицији” Бранко Златковић примећује ,једновремено одсуство култа кнеза Лазара Хребељановића" и смењивање приче о трансценденцији (избору небеског) - причом о акцији, жртвовању у земаљском животу. Радови Бранка Златковића, Дејана Илића и Данијеле Петковић објављени су у зборнику радова Савремена српска фолклористика 7, 2020.

${ }^{25}$ В. студију С. Милосављевић Милић Актуализација и ревалоризација националних идеологема у савременој српској прози, у којој се идеологема о патриотизму и издаји доводи у везу са метанаративом, историјским памћењем. Пишући о роману Месечева лађа, ауторка запажа: „Тако ће у роману Месечева лађа тема прогона једног дела српског народа са простора Косова и Метохије „призвати” у подтексту романа, али и непосредно прозвати у ауторском коментару догађаје из далеке прошлости, то јест саму Косовску битку као почетак трагичног усуда народа. Наравно, ова (ре)актуализација и сама полази од текстуалне, у овом случају, митске визије прошлости". Имајући у виду поред Стојановићевог поменутог романа, и романе Киша и хартија Владимира Тасића (2004), Четири зида и град Звонка Карановића (2006), ауторка закључује: „Осим прихватања текстуалних трагова прошлости, однос аутора према њима може бити и критички или полемички” (2013: 259).

${ }^{26}$ У том контексту индикативне су тврдње историчара Ненада Макуљевића: „Култ Косова је почетком 20. века добио југословенски карактер, а идеологија Видовдана постала је југословенска. Тако Иван Мештровић израђује пројекат и делове Видовданског храма који треба да отелотворе идеју југословенства" (Макуљевић 2006: 81). 
на прошлост, утискивање у садашњост, заправо је било у знаку императива будућег - она је артикулисала више жељену епску историју и њену свесустижну херојску правду, него догођену историју. Наративи су кружили кроз уроборос жеље која је неепску стварност усмеравала према епској: нешто се догодило, епски се приповедало о херојству догођеног ↔ није се догодило херојство, али се реинтерпретирао херојски чин; ${ }^{27}$ садашње је пролазило кроз епски филтер прошлог, чиме му се обезбеђивала жељена „епска” „светла” будућност. У том контексту велика прича се више није ни односила на конкретно историјско време у коме су субјект сазнања и историјски објект раздвојени, већ је попримала једну дубљу метафизичку димензију. ${ }^{28}$

Самеравање конкретних историјских личности (владара, на пример) са епски профилисаним јунацима или репертоарска политика позоришта које у циљу националне самопрезентације посебно место придаје историјским драмама - у великој мери потврђује и илуструје оптативност велике приче.

С једне стране су били они који су се залагали за њено обнављање, а с друге, они који су доводили у сумњу и причу и оне који се за њу залажу (чиме су је такође обнављали). Већ се у сатирама Радоја Домановића и у политичким говорима његових јунака препознавала једна реторика у којој се изгубила свака веза између означитеља, ознаке и означеног, у којој је велика косовска прича постала реторско средство ${ }^{29}$. Жељено је тумачено и као идентититски императив појединца, нације, али и као средство манипулације. Тако је велика прича постала и психолошка прича: о жуђеном, измишљеном, инспиративном, о истинској тежњи, али и о лажима и о манипулацији.

Рецепција велике косовске приче у 19. веку значајна је не само због канонизације „вуковске варијанте” приче, већ и због изразите експанзије наратива и профилисања два правца ширења; косовска велика прича фигуративно је постала и центрипетална и центрифугална сила новостворених наратива - једни су је потврђивали (историјска драма, на пример), а други су је такође обнављали, али супротстављајући јој се

${ }^{27}$ Ово се дешава чак и кроз минус приповедање, кроз причу о недостатку, о мањку, кроз ретроспективне утопије. Ретроспективну утопију, на пример, препознајемо у размишљањима јунака савременог романа Р. Стојановића Месечева лађа: „Косово је наш изгубљени рај. То велим и данас" (2005: 32).

28 О три стадијума историје и најсложенијој димензији историјског, о унутрашњој души историје и унутрашњој тајни историјског, в. Николај Берђајев, Смисао историје, 2002: 9.

${ }^{29} \mathrm{O}$ томе в. Д. Вукићевић: Косово и реторика антијунака, Савремена српска фолклористика 7, 2019. 
(battling narratives - Abot, The Cambridge Introduction to Narrative, 2008). Ово динамичко пулсирање велике приче кроз афирмацију и негацију тема је којом, међутим, излазимо из оквира рада посвећеног општим одликама велике приче и улазимо у поље новог рада инспирисаног узроцима њених разноврсних жанровских и идеолошких манифестација.

\section{ЛИТЕРАТУРА}

Абот 2009: Х. Портер Абот, Увод у теорију прозе, Београд: Службени гласник.

Бамберг 2008: M. Bamberg, Master narrative, Routledge Encyclopedia of Narrative Theory, London and New York.

Берђајев 2002: Н. Берђајев, Смисао историје. Ново средњовековље. Крај ренесансе, Београд, Бримо.

Велимировић 1994: Н. Велимировић, Религија Његошева, Подгорица, Пећ.

Домановић 2009: Р. Домановић, Приповетке, Сабрана дела Радоја Домановића 2, Крагујевац: Кораци.

Живковић 1970: Д. Живковић, Европски оквири српске књижевности, Београд: Просвета.

Јовићевић 2007: Т. Јовићевић, Српски историјски роман XIX века, Београд: Друштво за српски језик и књижевност Србије.

Костић 1987: Ђ. Костић, Кюижевни појмовник Вука Карачића, Београд: Народна књига.

Лазић 1998: Љ. Лазић, Изглед грађанских ентеријера у Новом Саду крајем 19. и почетком 20. века" ХІХ, Музеј Војводине, Нови Сад 1998, 249-261https://www.mpu.rs/zbornik/pdf/zbornik_6/4.pdf, прег. 03.06. 2019.

Луман 2010: Н. Луман, Љубав као страст, прилог кодирању интимности, Нови Сад.

Милосављевић Милић 2006: С. Милосављевић Милић, Интерпретаиијски кодови семантичке опозиције наше и страно у књижевности / Снежана Милосављевић Милић. У: Своје и чуждо в културата на Българи и Сърби/Своје и туђе у култури Бугара и Срба, Зборник радова, Велико Търново: Университетско издателство „Св. св. Кирил и Методий”, (2006), 11-25.

Милосављевић Милић 2008: С. Милосављевић Милић, Изазови кьижевног отпора - рецепиија стварности у савременом српском роману / Снежана Милосављевић Милић. У: Књижевност, друштво, политика, зборник радова, Крагујевац: Филум, 45-56. 
Милосављевић Милић С. 2013: Актуализација и ревалоризација националних идеологема у савременој српској прози, У: Фигуре читања / Снежана Милосављевић Милић. Београд: Службени гласник, 255-269.

Макуљевић 2006: Н. Макуљевић, Уметност и национална идеја у 19. веку, Београд.

Несторовић Зорица 2007: Богови, иареви и људи: Трагички јунак у српској драми XIX века, Београд: Чигоја штампа.

Павић, Милорад: Гаврил Стефановић Вениловић, LXV, 437, Београд: CK3 https://www.rastko.rs/rastko-hu/umetnost/knjizevnost/studije/mpavic-venclovic/mpavic-venclovic.html, прегл. 22. 11. 2020.

Петровић 2001: С. Петровић, Косовске битке у усменој поезији, Београд: Гутенбергова галаксија.

Пешикан Љуштановић 2009: Љ. Пешикан Љуштановић, Усмено у писаном, Београд: Београдска књига.

Пешикан Љуштановић 2020: Љ. Пешикан Љуштановић, Пимем ти причу, Нови Сад: Академска књига.

Пешикан Љуштановић 2009: Љ. Пешикан Љуштановић, Кад је била кнежева вечера?, Нови Сад: Позоришни музеј Војводне.

Пешикан Љуштановић 2008: Љ. Пешикан Љуштановић, Вукови записи као српска 'општепозната прича' Кюижевна историја, 136, 431-453.

Питулић 2011: В. Питулић, Трагом архетипа, Београд: Друштво за српску књижевност и језик.

Рељић: Љ. Раљић, Косовска легенда у народном стваралаштву, Београд: Етнографски музеј, б. г.

Рајан 2008: M. L. Ryan, Media and Narrative, Routledge Encyclopedia of Narrative Theory, London and NewYork.

Савремена српска фолклористика VI: зборник радова, Београд: Удружење фолклориста Србије: Универзитетска библиотека „Светозар Марковић”; Лозница: Центар за културу, „Вук Караџић”, 2019.

Самарџија 2018: С. Самарџија, Речи у времену, Београд: СКЗ.

Скерлић 1956: Ј. Скерлић, Писии и књиге, 3, Београд: Просвета.

Сремац б.г.: С. Сремац, Приповетке, Загреб.

Стојановић 2012: Д. Стојановић, Калдрма и асфалт, Београд: Удружење за друштвену историју.

Стојановић 2005: Р. Стојановић, Месечева лађа, Београд: Народна књига.

Тимотијевић 2005: М. Тимотијевић, Народно позориште у Београду - храм патиотске религије, Наслеђе, 6, 9-45.

Фрајнд 1987: М. Фрајнд, Политика и легенда у српској историјској драми, У: Историјска драма ХІХ века. Књ. 1, Београд: Нолит. 
Хамак 2010: P. L. Hammack, Identity as burden or benefit? Youth, historical narrative, and the legacy of political conflict. Human Development, 53, 173-201.

Хамак, Пилецки 2012: P. L. Hammack, A. Pilecki, Narrative as a root metaphor for political psychology. Political Psychology, 33, 75-103.

Хамак, Тулис 2015: P. L. Hammack, E. E. Toolis: Putting the Social into Personal Identity: The Master Narrative as Root Metaphor for Psychological and Developmental Science, https://www.karger.com/Article/FullText/446054, прегл. 15. 12. 2020.

Dragana B. Vukićević

\section{THE MASTER NARRATIVE AS ROOT METAPHOR FOR THE BATTLE OF KOSOVO}

\section{Summary}

The Kosovo myth existed in various forms for centuries. We are considering the Kosovo story as generic story, some kind of metaphor through which the past or current historical moments are (re)interpreted. In different genres, we recognized similar ways of creating a master narrative. Comparing the verbal and pictoral narrative, we tried to recognize status que, core story. The acters in that story are: a traitor who is not a traitor, a dead man who has come to life, an innocent slandered man. In the paradox we recognize the vitality of the story, its ability to spread.

Key words: Kosovo, master narratives, epics, genre, history, media. 